\title{
IMRE KERTÉSZ: EL HOLOCAUSTO COMO CULTURA
}

\section{Iñaki Vázquez Larrea}

Universidad Pública de Navarra

http://dx.doi.org/10.5209/NOMA.56573

"La ley de nuestro mundo es el error, el malentendido, el noreconocimiento del otro" (Imre Kertész, El Holocausto como Cultura, pag.15)

"Nuestra mitología moderna empieza con un gigantesco punto negativo: Dios creó el mundo y el ser humano creó Auschwitz" (Imre Kertész, El Holocausto como Cultura, pag.18)

Si Sandor Marai sentía perder "su yo" ante la perspectiva de regresar a Hungría en 1989 (poco antes de suicidarse en San Diego), Kertész lo hizo por el mero instinto de perro vagabundo, poco después de que su patria le pusiese en el disparadero de ser asesinado por la Alemania nazi, con tan sólo dieciséis años. Cuarenta años de socialismo real, no hicieron sino reforzar una inalterable extranjería. Poco antes de su muerte, Kertész reconocía que todavía la palabra patria le producía miedo. Al fin, y al cabo, durante su adolescencia, era forzado a cantar canciones patrióticas con el brazalete amarillo de judío puesto en el brazo.

No en vano, siempre se definió como un enemigo interno de su propio país, que durante cuatro décadas demostró ser más cárcel que hogar. El sujeto que abandona el totalitarismo, que se representa como realidad única y absoluta, pierde la seguridad rodeada de alambradas: "Aunque sólo sea de forma simbólica, emprende un peregrinaje del que no sabe adónde conduce, pero del que si puede asegurarse lo siguiente; cada vez lo aleja más de cualquier posible hogar o refugio" (Imre Kertész, El Holocausto como Cultura, pag. 24).

Kertész consideraba que los húngaros estaban muy lejos de considerar a Auschwitz como el acontecimiento traumático de la civilización occidental, para pasar a considerarlo como un mero asunto privado de judíos esparcidos por el mundo.

En consecuencia, para Kertész no existen diferencias conceptuales entre la experiencia del Gulag (soviético) y el Lager (nacionalsocialista); ningún totalitarismo de partido o de estado puede existir sin la discriminación, y la forma totalitaria de la discriminación es necesariamente la matanza. 
Para Kertész los orígenes del totalitarismo nazi, no están en la psicología freudiana, ni en el tradicional antisemitismo pagano germánico. Resulta de una infección moral que está en la definición misma del humanismo occidental durante los siglos XVIII y XIX. Es la ruptura cainita del legado ilustrado que pontificaba la igualdad jurídica de los judíos en Europa occidental tras la Revolución francesa; de ahí la naturaleza universalista del nacionalsocialismo y su carácter de enfermedad del espíritu europeo: "El provocador de escándalos, el Caín moderno, el que elige la ruptura como motor de su dinámica del poder, es decir, el que quiere entrar en la narración enfrentándose a su espíritu enseguida pone el antisemitismo en la bandera de su rebelión. Es un símbolo universal y supone una llamada clara y abierta a involucrarse y a ser cómplice. Por tanto, el antisemitismo a través del crimen cometido contra los judíos, es un crimen cometido contra un contrato legal y contra el alma todavía muy receptiva y sensible a este contrato. Así declaró el movimiento nazi su aspiración a la universalidad: por otra parte, así se hizo inmortal su atroz crimen" (Imre Kertész, El Holocausto como Cultura, pag. 61).

Adorno decía que después de Auschwitz no hay poesía, para Kertész el legado de Auschwitz es la infelicidad del ser humano, por haber arruinado la posibilidad de cualquier proyecto de autonomía personal. Las posibilidades de catarsis en un mundo atomizado resultarían endebles, la tragedia griega o la creatividad del lenguaje. Con todo Kertész guarda en su relato un atisbo de esperanza. En nuestro mundo moderno o posmoderno nos dice: "Las fronteras no aparecen transcurrir tanto entre grupos étnicos, naciones y confesiones, cuanto entre concepciones del mundo y actitudes ante el mundo, entre razón y fanatismo, entre paciencia e histeria, entre creatividad y deseo aniquilador de poder" (Imre Kertész, El Holocausto como Cultura, pag.123).

\section{BIBLIOGRAFÍA:}

KERTÉSZ, I: Sin Destino, Acantilado, Barcelona, 2006.

KERTÉSZ, I: Un Instante de Silencio en El Paredón (El Holocausto como Cultura), Herder, Barcelona, 1999. 